\title{
Comparative Studies on Clarias gariepinus Pituitary Extracts and Synthetic Hormone on Induced Spawning and Growth Performance of the African Catfish Clarias gariepinus Fry
}

\author{
Abdul Rahman $\mathrm{BH}^{1}$, Edward Kadala ${ }^{2}$ and Sogbesan Olukayode $\mathrm{A}^{3 *}$ \\ ${ }^{1}$ Department of Biology Education, Federal College of Education, Nigeria \\ ${ }^{2}$ Department of Zoology, Modibbo Adama University of Technology, Nigeria \\ ${ }^{3}$ Department of Fisheries, Modibbo Adama University of Technology, Nigeria
}

Submission: July 10, 2017; Published: October 18, 2017

*Corresponding author: Sogbesan Olukayode A, Department of Fisheries, Modibbo Adama University of Technology, Yola, Nigeria, Email: sokayfish@gmail.com

\begin{abstract}
Comparative Studies on Clarias gariepinus Pituitary Extracts and Synthetic Hormone on Induced Spawning and Growth Performance of the African Catfish Clarias gariepinus Fry was carried out at the hatchery unit of the Fisheries Department Farm of the Modibbo Adama University of Technology Yola, Adamawa State, Nigeria. Twelve Catfish brood stocks were used for the breeding. Two other catfish broods were sacrificed for the extraction of pituitary extract to induce the brood catfish. Ovaprim was also used as the synthetic induce hormone as control ( $\left.\mathrm{T}_{1}\right)$ for male and female injected with $100 \%$. The treatment includes the following; $\mathrm{T}_{2}, \mathrm{~T}_{3}, \mathrm{~T}_{4}$ and $\mathrm{T}_{5}$ for each treatment two brood stocks a male and female is treated with same level of hormone $\mathrm{T}_{2}$ (African catfish pituitary extract-ACPE, $100 \%$ ), $\mathrm{T}_{3}$ Combined inducers with $(50 \%$ synthetic-50\% ACPE), $\mathrm{T}_{4}\left(25 \%\right.$ ACPE and $75 \%$ ovaprim) and $\mathrm{T}_{5}(25 \%$ ovaprim and $75 \%$ ACPE). The relative fecundity was higher for the brood fish treated with $\mathrm{T}_{2}$ with (38.37\%) comparing it with the lowest $\mathrm{T}_{4}$ with (27.88\%). The latency and hatchability periods were between 9.05-12 and 48 hours respectively for each of the female across the treatment. The female fish injected with ovaprim $100 \%\left(\mathrm{~T}_{1}\right)$ has lower percentage hatchability (56.30\%) compared with those injected with $100 \%$ ACPE $\mathrm{T}_{2}$ (60.99\%). The combination of ovaprim and ACPE at different doses were also observed, the combination of $25 \%$ ovaprim and $75 \%$ ACPE also recorded a remarkable values of hatchability percentage (59.39\%) compared to the $50 \%$ ovaprim and $50 \%$ ACPE. Survival rates also followed the same pattern with the hatchability rate. The survival rate was higher in female treatment with 100\% ACPE (92.60\%) And lower in fish treated with 100\% ovaprim (63.45\%) The growth rate of the fry also showed significant difference between the fry treated with different inducers; the $\mathrm{T}_{2}$ has the highest growth rate ranging from of 0.029-0.236 and the lowest with 0.029-0.200 for $\mathrm{T}_{4}$. Other parameter also includes the Mean weight gain of 0.217 of $\mathrm{T}_{2}$ which is the highest and the lowest with 0.171 for $\mathrm{T}_{4}$. Specific growth rate of $\mathrm{T}_{2}$ with 0.896 which is the heist And $\mathrm{T}_{4}$ having the least with $0.685 \mathrm{bt}$ fir relative growth rate $\mathrm{T}_{2}$ has the lowest with 14.01 and 16.96 for $\mathrm{T}_{4}$ The results showed both ACPE and ovaprim aided spawning in African catfish although female fish treated with ACPE enhanced higher hatchability and fries produced from ACPE injected female had higher survival rate, therefore it can be concluded that ACPE hormone yielded the best results in fish seed production
\end{abstract}

Keywords: Pituitary extract; Synthetic hormone; Induced spawning; Clarias gariepinus; Fry

\section{Introduction}

Globally, the demand for fish is geometrically growing along with the population growth, urbanization and increasing wealth (World Bank, 2013). The World Bank reported that per capita fish consumption will increase fastest in rich countries and in some parts of the world, such as China, where aquaculture thrives, leading to growing regional disparities between supply and demand (World Bank, 2013). Most worrying, however, are the declines in projected consumption for sub-Saharan Africa, where, levels of food and nutrition insecurity with poverty are alarming. Fish makes up such a high proportion of about (32\%) of animal-source foods. The World Bank (2013) estimates that per capita fish supplies in sub-Saharan Africa is likely to shrink by $1 \%$ per annum, from $6.8 \mathrm{~kg}$ in 2010 to $5.6 \mathrm{~kg}$ in 2030 ; this is by far the lowest in the world with global average of $18.2 \mathrm{~kg}$, this will increase trade incident of the fish in the international market. 
Aquaculture remains the only viable alternative for increasing fish production in order to meet the protein needs of the people. No other group of vertebrate serves man in so many forms as fish [1]. African Catfish (Clarias gariepinus) is a hardy species for aquaculture purpose. It is widely accepted in the tropics and commands good commercial values, Even though, the species hardly breeds in captivity all year round efforts is to be intensify on research for it artificial seed production [2]. Several researchers have shown that pituitary hypophysation is effective in inducing the spawning of C. gariepinus. Nigeria is the leading catfish fish producer in Africa but this could still be improved upon by availability of induced spawning hormones. Synthetic hormones have been used to induce maturation, spawning and ovulation by using GnRH Analog with Dopamine Antagonist and Luteinizing hormone releasing hormone (LHRH). Ovaprim, which is a combination of Salmon GnRH analog combined with a dopamine, has proved to be extremely successful in breeding of Clarias gariepinus. Sex steroids in female fish perform major roles in Oocyte maturation, ovulation and spawning. Synthesis of vitellogenin and increase in ovarian size during final oocyte maturation is controlled by $17 \mathrm{~b}$-estradiol, which is directly related to gonad somatic index [3]. Although a trend exist to apply alternative synthetic hormone substances to induce spawning in catfish and other cultured fishes, hypophysation still remains the most common technique. This method is still widely employed particularly for the fish which are economically very essential but do not spawn in confined waters of aquaculture. Clarias pituitary extract (CPE) and Luteinizing hormone-releasing hormone analogue (LHRHa) are two well-known hormones for controlling ovulation in Channel catfish [4].

To solve the problem of quality fish seed availability, induced breeding technique through the use of fresh Clarias pituitary extract for induction of gonad maturation and ovulation of the same fish species should be exploited. Depending on commercial hormones that are difficult to come by, costly and some adulterated cannot help fish farmer, rather using natural pituitary extract [5] could be a viable substitute.

\section{Materials and Methods}

\section{Study area}

The study was carried out at the hatchery unit of the Fisheries Department Farm of the Modibbo Adama University of Technology Yola, Adamawa State, Nigeria. Yola as shown lies between latitude 9 "” 130 North and longitude 12"27 o East (Wikipedia, 2015 retrieved).

\section{Brood stock selection}

The brood stock of the C. gariepinus was obtained from the Federal Department of Fisheries Yola, fish farm; and was acclimatized in the concrete tank of the Fisheries Department Farm of the Modibbo Adama University of Technology Yola for 24 hours. The mature gravid females were selected based on well distended swollen soft abdomen, reddish vent, and gentle extraction of few eggs by depressing of the fish abdomen using the finger. Mature males were also selected based on their reddish pointed genital papillae [6].

\section{Source of hormone}

Non synthetic hormone: Pituitary extract were collected from matured Males and Female Bloodstock each using the method of [7]. A specimen must be sacrificed and the head cut off so as to access the brain easily using either hacksaw or well sharpen knife the head is divided in the middle by the mouth leaving the surface of the bone of the head.

The pituitary is found as small round shaped organ, pinkwhite, situated at the vent part of the basis (Selle turica). Each gland is then weight and transferred into a seal test tube containing $0.9 \%$ Normal saline, it was then pulverized in a proclaim mortar with $3 \mathrm{ml} /$ normal saline solution till smooth and ready for injecting .

Synthetic hormone: For the synthetic hormone, Ovaprim was used, the Ovaprim is produced by Syndell laboratories, Canada during the early 1990 and up till today it is being used as an inducer for fertility, the product is liquid containing D-Arg6, Pro9, Net s-GnRH and domperidone, it contain $20 \mathrm{mg}$ of salmon ganodotropin and $10 \mathrm{mg}$ of domperidone per $\mathrm{ml}$ of inject able solution dissolved in an organic solution, single application of ovaprim was used as described by $[8,9]$.

Table 1: Dosage of Synthetic (Ovaprim) and Non Synthetic (ACPE) Used in Female Treatments.

\begin{tabular}{|c|c|c|c|}
\hline Treatments & ABW (g) & Hormones & $\begin{array}{c}\text { Dose/kg Body } \\
\text { Weight (ml) }\end{array}$ \\
\hline T1 & 1600 & $100 \%$ ovaprim & 0.5 \\
\hline T2 & 700 & $100 \%$ ACPE & 0.35 \\
\hline T3 & 1450 & $\begin{array}{c}50 \% \text { ovaprim }+ \\
50 \% \text { ACPE }\end{array}$ & $0.725+0.3625$ \\
\hline T4 & 1300 & $\begin{array}{c}25 \% \text { ACPE }+75 \% \\
\text { ovaprim }\end{array}$ & $\begin{array}{c}0.08125+ \\
0.1625\end{array}$ \\
\hline T5 & 1600 & $\begin{array}{c}25 \% \text { ovaprim }+ \\
75 \% \text { ACPE }\end{array}$ & $0.35+0.5$ \\
\hline
\end{tabular}

Hormone injection: The male and female brood stock were weighed separately using a $10 \mathrm{~kg}$ Camry Premium Table weighing balance Table 1 . The females were injected based on their weight with a pituitary gland extract collected from the mature C. gariepinus males and the Ovaprim hormone procure from the market respectively. The pituitary gland extract (nonsynthetic hormone) was administered intramuscularly (above the lateral line, towards the tail) at the recommended rate of $1 \mathrm{ml}$ per $\mathrm{kg}$ body weight of female fish and half dosage for male [10]. The Ovaprim (synthetic hormone) was administered intramuscularly (above the lateral line, towards the tail) at the recommended rate of $0.5 \mathrm{ml}$ per $\mathrm{kg}$ body weight of female fish and half dosage for male [10]. After the injection, the brood stock was kept back into the concrete tank, with the males being separated from the females for a latent period of 12 hours. 
Dosage of Synthetic (Ovaprim) and Natural (African Catfish Pituitary Extract) Hormone Used on Female Treatments. The dosage of synthetic (ovaprim) and natural (African catfish pituitary extract) hormone used in the treatment of female Clarias gariepinus brood stock was based on their average body weight of the female fish taken before the experiment.

\section{Dosage of synthetic (ovaprim) and natural (African catfish pituitary extract) hormone used on male treatments}

The dosage of synthetic (ovaprim) and natural (African catfish pituitary extract) hormone used in the treatment of male Clarias gariepinus brood stock was based on their average body weight of the male before the experiment.

\section{Dosage of combine inducers (synthetic and natural) hormones used on both female and male brood stocks}

The dosage of combine inducers used to induce both female and male brood stocks were based on the average body weight during the experiment.

\section{Determination of optimum latency periods}

Determination of optimum latency period using clarias pituitary extract: The treatments used were replicated twice with measured amount of the extract $1 \mathrm{ml} / \mathrm{kg}$ per fish [11]. For the treatment on $100 \%$ natural hormone (pituitary extract) twelve hours latency period (treatments) that is the time between hormone injection and the time ready for stripping was monitored on hourly basis to check if it is ready for stripping. After it was injected and were placed in an aerated plastic trough and covered with Nets and tied with rubber tube to avoid jumping out of the brooders for that period of time [11].

Determination of optimum latency period using synthetic hormones : Hormone (Ovaprim) is administered to the brooder at $0.5 \mathrm{ml} / \mathrm{kg}$ for treatment of $100 \%$ synthetic hormone treatment, eight to ten hours latency period (treatments) that is the time between hormone injection and the time ready for stripping was monitored on hourly basis, no replication for this treatment. After it was injected and were also placed in an aerated plastic trough and covered with Nets and tied with rubber tube to avoid jumping out of the brooders for that period of time.

Effectiveness of using combined inducers: The effectiveness of using combine inducers of $50 \%, 50 \%$ and $75 \%, 25 \%$ Ovaprim and pituitary extracts respectively, their effectiveness was prominent as described [12].

Relative fecundity: Number of mature oocytes in a female divided by the total weight of that female.

\section{Milt and eggs collection}

The milt was collected by sacrificing the male. The two lobes of the male's testes were removed, cleaned with tissue paper and kept in a cleaned Petri dish. The abdomen of the female was well cleaned with tissue paper in order to avoid contact between the eggs and water. Then the females were stripped of their eggs by a gentle application of pressure on the abdomen to release the eggs. The eggs were collected in a dry, well cleaned plastic bowl Figure 1.

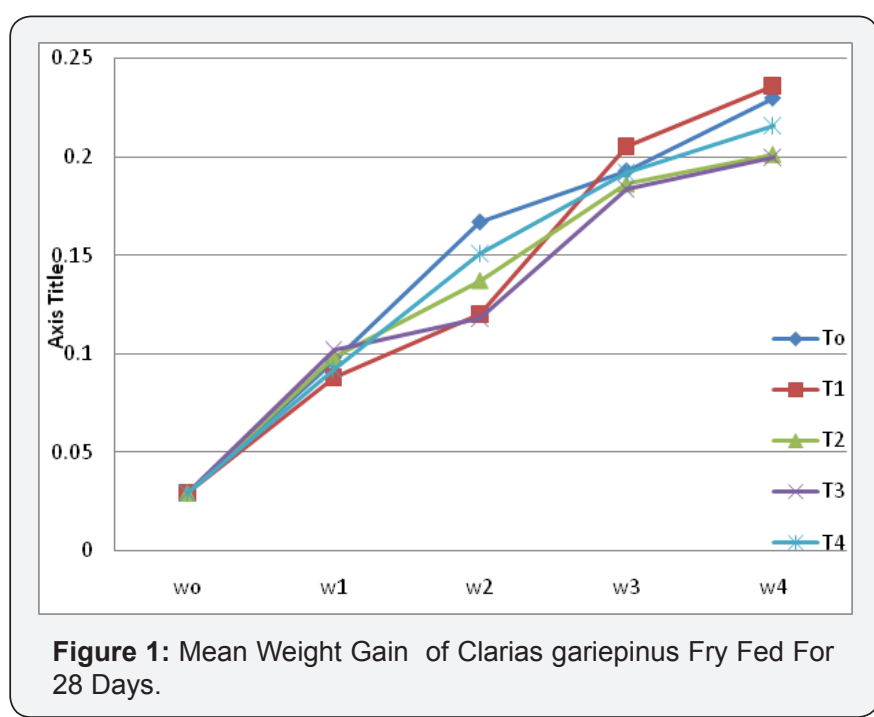

\section{Artificial fertilization}

The testes of the male was cut open using a razor blade and the milt was squeezed out, and then $0.9 \%$ saline solution $(\mathrm{NaCl})$ was added to the milt in order to facilitate fertilization after which the milt was used in fertilizing the already stripped eggs. It is a dry fertilization hence the percentage fertilization was calculated [12].

\section{Hatchability period}

The hatchability period is the period required for incubation of the eggs from initiation to complete incubation of the eggs which is 48 hours.

Percentage hatchability: The number of hatchlings was estimated using the volumetric method. The hatchling after swimming into the happa tanks containing 900 Liters of water, a sample of 1 liter was collected and the number of hatchlings was estimated from the sample. The percentage hatchability was calculated from the number of fry counted as described by [13].

$$
\text { Percentage hatchability }=\quad \frac{\text { Number of hatched eggs }}{\text { Numberof Eggs weight }} \times 100 \quad \ldots . . . . . . . . . . . .11
$$

Incubation and hatching of eggs: Incubation and hatching of eggs was carried out in 5 aerated hatchery tanks with each measuring 1,000 liters. Each hatchery tank was filled with 900 liters of water containing incubation nets of $1 \mathrm{~mm}$ mesh size for substrate attachment of eggs. The fertilized eggs were evenly spread on the incubation nets in the tanks at temperatures between $26-32^{\circ} \mathrm{C}$.

Feeding of larvae: Three days after hatching, after all yolk reserved had been re-absorbed, feeding of the new hatchlings started exogenously. 
Culture of live food for the fry: The rotifers used in feeding the larvae; a zooplankton of the genus Brachionus was cultured in the Fisheries Department Farm of the Modibbo Adama University of Technology Yola as described by [14].

\section{Experimental set-ups}

The experiment was subjected to a complete randomized design (CRD) with 5 experimental sets in replicates consequently $5 \times 2$ giving a total of 10 experimental units. In this study, 6 female Brood fish and 6 male Brood fish making the total of 12 brood stocks was used for the study. Two brood fish were sacrificed for the pituitary gland, the remaining ten were used for the treatments, that is one male and one female for each the treatments. The treatments were designated as $T_{1}, T_{2}, T_{3}, T_{4}$ and $\mathrm{T}_{5}$ respectively. Treatment $\mathrm{T}_{1}$ was $100 \%$ synthetic hormone (Ovaprim) administered to both Male and Female brood stock base on the size of the fish as control, treatment T2 100\%. Pituitary extract treatment to both the Male and Female base on the size of the brood fish, treatment $\mathrm{T}_{3} 50 \%: 50 \%$ of both pituitary and Ovaprim combine treatment to both fishes base on it sizes., treatment $\mathrm{T}_{4}$ 25\%:75\% treatment of Ovaprim and pituitary treatment to both fishes respectively, base on it, treatment $T_{5}$ 72\%:25\% treatment of pituitary and Ovaprim treatment to both fish respectively. The Fry were fed at a fixed feeding rate of $10 \%$ body weight 4 times daily between the hours of 07:00 and 23:00 at regular interval for a period of 28 days with live food.

\section{Water quality parameters}

Water quality parameters such as $\mathrm{pH}$, temperature, dissolved oxygen and ammonia were monitored twice weekly, using $\mathrm{pH}$ meter, mercury in bulb thermometer, dissolved oxygen test kit and an ammonia test kit respectively.

\section{Fish weight measurement}

The initial body weight of each set of fish was measured using a sensitive weighing balance before stocking and subsequently bulk weighing of fish in each tank was done after every 15 days.

\section{Analysis of fish growth and nutrients utilization}

The growth was expressed as mean weight gain; specific growth rate and survival rate [15]. Nutrient utilization indices were expressed as feed conversion ratio and protein efficiency ratio [16].

Mean weight gain (MWG): The fish mean weight gain was determined as the difference between the final mean weight of the fish at the end of the experiment and the initial mean weight in grams [17].

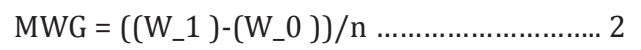

Where: $\mathrm{W} 0$ = initial mean weight; $\mathrm{W} 1=$ final mean weight; $\mathrm{n}$ $=$ number of fish in the tank

Specific growth rate (SGR): This is the mean percentage increase in body weight per day over a given time interval [18].
In this study, the time interval is 28 days.

$$
S G R=\left(\left(L_{-} n\right)\left(W_{-} 1\right)-\left(L_{-} n\right)\left(W_{-} 0\right)\right) / T \times 100
$$

Where: $\mathrm{W} 1$ = final mean weight; $\mathrm{W} 0=$ initial mean weight; $\mathrm{T}$ $=$ time interval

Survival rate (SR): Survival rate was also determined as defined by the equation below [19].

SR $(\%)=$ N_1 1 N_0 $\times 100$. 4

Where:

$\mathrm{N} 1=$ Final number of fish at the end of the experiment

$\mathrm{N} 0=$ Initial number of fish at the beginning of the experiment.

\section{Cost analyses}

a. Cost of natural hormone $=\# 1000 \times 3.005575 \mathrm{ml}=30005.75$

b. Cost of synthetic hormone $=\# 700 / \mathrm{ml} \times 2.525 \mathrm{ml}=1767.5$

c. Cost of fry produced = Hatchability $\mathrm{x}$ no. of fry produced $\mathrm{x}$ amount sold ....... 5

d. Net profit $=$ cost of fry produced - cost of hormone ... 6

Cost Benefit Ratio $=\frac{\text { Cost of fry }}{\text { Cost of hormones }}$

\section{Statistical Analysis}

The result obtained was subject to one way analysis of variance (ANOVA). The statics differences between the treatments means were separated using Duncan's multiple range tests [20]. SPSS [21] statistical package for windows software was used to run the result.

\section{Results}

\section{Water quality parameters taken from the experimental tanks for the hatching period}

Table 2: Water Quality Parameters Taken from the Experimental Tanks during Hatching Period.

\begin{tabular}{|c|c|c|c|c|c|}
\hline Parameters & T1 & T2 & T3 & T4 & T5 \\
\hline Temperature (oC) & 28.6 & 27.6 & 28.6 & 26.6 & 27.6 \\
\hline $\mathrm{pH}$ & 6.5 & 6.5 & 6.4 & 7.1 & 6.2 \\
\hline Dissolved Oxygen (mg/l) & 5.2 & 6 & 6 & 5.9 & 5.4 \\
\hline Ammonia (mg/l) & 0.04 & 0.03 & 0.03 & 0.02 & 0.03 \\
\hline
\end{tabular}

Table 2 shows water quality parameters taken from the experimental tank during hatching period. The temperature range was within 27.6 - 28.6; while $\mathrm{pH}$ was between the ranges of $6.2-7.1$. Dissolved oxygen was within the ranges of 5.2 to 6.0 and ammonia was within the range of $0.02-0.04$.

\section{Induced ovulation and spawning of Clarias gariepinus using synthetic (ovaprim) and non synthetic (African catfish pituitary extract) hormones}

Table 3 shows the average body weight, mean egg weight, relative fecundity, and hatchability, survival rate, hatching 
periods and latency periods of all the treatments while $\mathrm{T}_{2}$ recorded the highest survival rate of $92.60 \%$ and $\mathrm{T}_{1}$ recorded the lowest survival rate of $63.45 \%$. Hatchability of $60.99 \%$ was recorded in $\mathrm{T}_{2}$ which was the highest and the lowest hatchability of $56.30 \%$ was recorded in $\mathrm{T}_{1}$ treatment. Mean egg weight of $177.98 \%$ was recorded in $\mathrm{T}_{2}$ which was the highest while the lowest mean egg weight of $92.75 \%$ was recorded in $\mathrm{T}_{4}$ [22-25].

Table 3: Induced Ovulation and Spawning of Clarias gariepinus Using Synthetic (Ovaprim) and Non Synthetic (African Catfish Pituitary Extract) Hormones.

\begin{tabular}{|c|c|c|c|c|c|}
\hline Parameters & $\mathbf{T}_{\mathbf{1}}$ & $\mathbf{T}_{\mathbf{2}}$ & $\mathbf{T}_{3}$ & $\mathbf{T}_{4}$ & $\mathbf{T}_{\mathbf{5}}$ \\
\hline ABW (g) & $1600_{\mathrm{a}}$ & $700_{\mathrm{d}}$ & $1450_{\mathrm{b}}$ & $1300_{\mathrm{c}}$ & $1600_{\mathrm{a}}$ \\
\hline MEW (g) & $116.75_{\mathrm{b}}$ & $177.98_{\mathrm{a}}$ & $106.75_{\mathrm{c}}$ & $92.75_{\mathrm{d}}$ & $120.75_{\mathrm{b}}$ \\
\hline Relative fecundity & $29.36_{\mathrm{c}}$ & $38.37_{\mathrm{a}}$ & $29.16_{\mathrm{c}}$ & $27.88_{\mathrm{d}}$ & $30.26_{\mathrm{b}}$ \\
\hline Hatchability (\%) & $56.30_{\mathrm{d}}$ & $60.99_{\mathrm{a}}$ & $58.41_{\mathrm{b}}$ & $57.34_{\mathrm{c}}$ & $59.39_{\mathrm{b}}$ \\
\hline $\begin{array}{c}\text { Hatching Periods } \\
\text { (hrs) }\end{array}$ & $48.00_{\mathrm{a}}$ & $48.00_{\mathrm{a}}$ & $48.00_{\mathrm{a}}$ & $48.00_{\mathrm{a}}$ & $48.00_{\mathrm{a}}$ \\
\hline Latency (hrs) & $9.05_{\mathrm{d}}$ & $12.00_{\mathrm{a}}$ & $11.00_{\mathrm{b}}$ & $100_{\mathrm{c}}$ & $9.08_{\mathrm{d}}$ \\
\hline Survival (\%) & $63.45_{\mathrm{d}}$ & $92.60_{\mathrm{a}}$ & $88.65_{\mathrm{c}}$ & $89.34_{\mathrm{b}}$ & $90.15_{\mathrm{b}}$ \\
\hline
\end{tabular}

\section{The rate of growth of fry taking after every seven days for 28 days.}

Table 4: Growth Parameters of the Fry.

\begin{tabular}{|c|c|c|c|c|c|}
\hline Parameter & $\mathbf{T}_{\mathbf{1}}$ & $\mathbf{T}_{\mathbf{2}}$ & $\mathbf{T}_{\mathbf{3}}$ & $\mathbf{T}_{\mathbf{4}}$ & $\mathbf{T}_{\mathbf{5}}$ \\
\hline Initial weight $(\mathrm{g})$ & 0.029 & 0.029 & 0.029 & 0.029 & 0.029 \\
\hline Final weight $(\mathrm{g})$ & 0.23 & 0.236 & 0.201 & 0.2 & 0.216 \\
\hline Mean weight gain & 0,201 & 0.207 & 0.172 & 0.171 & 0.187 \\
\hline Relative Growth Rate & 14.42 & 14.01 & 16.86 & 16.95 & 15.5 \\
\hline Specific growth rate & 0.817 & 0.896 & 0.689 & 0.685 & 0.757 \\
\hline
\end{tabular}

Table 4 shows the rate of growth of fry taking after every seven days for 28 days, the initial weight of all the fry after hatching was $0.029(\mathrm{gm}) \mathrm{T}_{1}$ the control range from 0.029 $0.230(\mathrm{~g}) \mathrm{T}_{2}$ growth range from $0.029-0.236(\mathrm{~g})$ which shows the highest, growth rate the growth $\mathrm{T}_{3}$ range from $0.029-0.201(\mathrm{~g})$, the growth of $\mathrm{T}_{4}$ range $0.029-0.200(\mathrm{~g})$. For $\mathrm{T}_{5}$ the growth rate range from $0.029-0.216(\mathrm{~g})$ it is clear that the fry for $\mathrm{T}_{2}$ the final weight of 0.236 has the highest weight and $\mathrm{T}_{4}$ has the lowest with $0.200(\mathrm{~g})$ at 28 days the growth parameter taken for the fry includes; the initial and final weights, relative growth weight, mean weight gain and specific growth rate.

Table 5: Cost Analysis of Using Different Hormones to Produce Clarias Gariepinus Fry.

\begin{tabular}{|c|c|c|c|c|}
\hline Treatments & Cost of Fry (\#) & Cost of Hormones (N) & Net Profit (N) & Cost Benefit Ratio \\
\hline $\mathrm{T}_{1}$ & 10556.3 & 1767.5 & $8,788.50$ & 5.97 \\
\hline $\mathrm{T}_{2}$ & 11143.8 & 3005.75 & 8138 & 3.71 \\
\hline $\mathrm{T}_{3}$ & 12828.7 & 1591.125 & 11237.58 & 8.06 \\
\hline $\mathrm{T}_{4}$ & 10741.3 & 2076.437 & 8664.61 & 5.17 \\
\hline $\mathrm{T}_{5}$ & 11118.8 & 2696.1875 & 8422.56 & 4.12 \\
\hline
\end{tabular}

In Table 5 the growth parameter taken for the fry includes; the initial and final weights, relative growth weight, mean weight gain and specific growth rate. The initial weight was the same for the hatched fry for the whole treatment at the end of 7 days and the final weight gained ranging from $0.200-0.236(\mathrm{~g}) \mathrm{T}_{5}-\mathrm{T}_{3}$ this shows that there is significant difference of the fry hatched from 100\% ACPE than other treatment. The mean gain weight of $\mathrm{T}_{4}$ which obviously higher with $0.207(\mathrm{~g})$ and lowest with $\mathrm{T}_{5}$ with $0.171(\mathrm{~g})$ induced with $100 \%$ ACPE and $25 \%$ ACPE $+75 \%$ ova prim respectively. The relative growth rate of the fry ranged from 16.96 for $\mathrm{T}_{5}$ and $14.01(\mathrm{~g})$ for $\mathrm{T}_{3}$ the specific growth rate for the fry also ranged from 0.896 for $\mathrm{T}_{3}$ and 0.685 for $\mathrm{T}_{5}$.

\section{Discussion}

The study observed the induced spawning and hatching of fries of (Clarias gariepinus) treated with synthetic (ovaprim) and non-synthetic (African catfish pituitary extract, ACPE) hormones.
It also shows the survival rates of the fry for the period of four weeks. Weight of gravid female used in each treatment ranged from $700 \mathrm{~g}-1600 \mathrm{~g}$.

All the fish responded well to both the synthetic (ovaprim) and the non-synthetic (African catfish pituitary extract) hormones. The spawning occurred within 9.05-9.08hrs after injection at a constant temperature of $27^{\circ} \mathrm{C}$, the study shows the success of using African catfish pituitary extract (ACPE) in fry production. The latency period for induced ovulation and spawning is higher in $\mathrm{T}_{2}$ with $100 \%$ ACPE having 12.00 and lesser with $\mathrm{T}_{1}$ with $100 \%$ ovaprim having 9.05 which served as the control this was not in line with [26] who stated The latency period of African Catfish using (GnRHa) combine dopamine antagonist hormone ranged from 10.33 to 15 hours for the seven ovulated groups (Table 6). Data demonstrated significant differences among these groups. The lowest latency period was (10.33 hours) in group 9. In the 
contrary, the longest latency period was (15 hours) in group 3. It is also not in line with [27] who stated that, the maximum latency period of 11 hours, 20 minutes is recorded in a study, this could be as a result of ovaprim dosage-dependent as was observed for mammalian gonadotropin, methyl testosterone and partially purified Salmon gonadotropin.

Table 6: Dosage of Synthetic (Ovaprim) and Non Synthetic (ACPE) Used in male Treatments.

\begin{tabular}{|c|c|c|c|}
\hline Treatments & ABW (g) & Hormones & Dose/kg Body Weight (ml) \\
\hline $\mathrm{T}_{1}$ & 550 & $100 \%$ ovaprim & 0.275 \\
\hline $\mathrm{T}_{2}$ & 1000 & $50 \%$ ovaprim $+50 \%$ ACPE & 0.5 \\
\hline $\mathrm{T}_{3}$ & 450 & $25 \%$ ACPE $+75 \%$ ovaprim & $0.1125+0.225$ \\
\hline $\mathrm{T}_{4}$ & 500 & $25 \%$ ovaprim $+75 \%$ ACPE & $0.625+0.125$ \\
\hline $\mathrm{T}_{5}$ & 550 & $0.275+0.362$ \\
\hline
\end{tabular}

Keys:

$\mathrm{T}_{1}=$ Control $100 \%$ Ovaprim; $\mathrm{T}_{2}=$ Treatment 1 100\% ACPE

$\mathrm{T}_{3}=$ Treatment 2 50\% Ovaprim+50\% ACPE; $\mathrm{T}_{4}=$ Treatment $325 \%$ ACPE + 75\% Ovaprim

$\mathrm{T}_{5}=$ treatment $425 \%$ Ovaprim $+75 \%$ ACPE; ACPE = African Catfish Pituitary Extract

$\mathrm{ABW}=$ Average Body Weight

The hatching rate was higher in $\mathrm{T}_{2}$ and lower in $\mathrm{T}_{1}, \mathrm{~T}_{5}$ which was a combined inducer also recorded a high hatchability rate of $59.39 \%$, and there is significances difference in the hatchability rates in all the treatments. These values do not agree with Olaniyi \& Akinbola [28] that reported the hatching rates of $46.3 \%$ in ovaprim and 25.99\% in ACPE in African catfish Clarias gariepinus, this study is not also in agreement with Saidin [29] who reported that artificial ovipositor by stripping of $C$. gariepinus gave low hatching rates of $10-45 \%$. The differences observed in these study compare to the work of the above cited authors may be as a result of handling and water quality parameters maintained during the hatching periods.

According to Olaniyi \& Akintola [30] fry absorb their Yolk sac after three days but the results of the research showed that fry from $\mathrm{T}_{1}$ did not completely absorb their yolk sac. However, the fry from $\mathrm{T}_{2}$ absorbed their yolk sac completely. This could be as a result of delay in hatchability of $\mathrm{T}_{1}$ or the temperature of the incubation tank as in line with Woynovorich \& Horvath [31] who stated that a number of environmental factors such as temperature, $\mathrm{pH}$, dissolved oxygen and calmness to play decisive role in ovulation and that temperature are of vital importance. Faster growths were observed in ACPE after feeding commenced compared to fries produced from ovaprim.

In this study the growth rate is also higher in $\mathrm{T}_{2}$ which is within 0.029-0.236 and lesser in $\mathrm{T}_{4}$ with $0.029-0.200$, feeding started to some of the fry with Rotifer (live feed) three days after complete absorption of the yolk sac for $\mathrm{T}_{2}$ while other five days after their completion absorption of the yolk sac, this could be the reason of their delay in growth [32-36]. The survival rate of fry after four weeks was higher in $\mathrm{T}_{2}$ and lower in $\mathrm{T}_{1}$ generally; it was observed that there is significant difference in the survival rate of fry after four weeks in all treatments $(\mathrm{P}<0.05)$.

This study is in accordance with Olaniyi \& Akinbola [37] who reported $50.14 \%$ in ovaprim and $82.98 \%$ in ACPE in four weeks rearing hatched fry of African catfish (Clarias gariepinus). This study also agreed with the work of Adebayo \& Popoola [38] who observed survival rate of greater than $60 \%$ after thirty days of rearing hatched fry of African catfish (Clarias gariepinus). The cost of fry produced is highest in $\mathrm{T}_{3}$ and lowest In $\mathrm{T}_{2}$, The cost of hormone used was also higher in $\mathrm{T}_{2}$ and lower in $\mathrm{T} 3$ this was because of the high cost of hormone used, The Net profit was also higher in $\mathrm{T}_{3}$ and lower in $\mathrm{T}_{1}$. The Cost Benefit Ratio is higher in $\mathrm{T}_{3}$ and lower in $\mathrm{T}_{2}$ with lower production profit. This is almost close to the findings of Olaniyi \& Akinbola [39] who reported to have almost same value of cost of production as in $\mathrm{T}_{2}$ (ACPE) compared with ova prim. In the same vein, ACPE had higher gross profit $(\mathrm{N} 68,060)$ and ova prim treated females had lower value (N 42,485.24). Based on this study, it is suggested that fish seed production can be encouraged through the use of natural hormones (African catfish pituitary extract) which is more readily available unlike the synthetic hormone (ovaprim) whose supply varies with changes in import duties [40-44].

\section{References}

1. Omitoyin B (2007) Introduction to fish farming in Nigeria. Ibadan University press, publishing. University of Ibadan. Nigeria, pp. 1-6.

2. Oguntuase BG, Adebayo OT (2014) Sperm quality and reproductive performance of male C. gariepinus induced with Synthetic Hormone (Ovatide and ovaprim). International. Journal of Fisheries and Aquaculture 6(1): 9-15.

3. Coccia E, De-lisa E, Di-cristo C, Cosso A, Paulucci M (2010) The effects of estradiol and progesterone on the reproduction of fresh water crayfish Cherax albidus. Biol Bull 218(1): 36-47.

4. Fobes MC (2013) Control spawning of white Cat fish Ictalurus Catus Brown bull head catfish Ameilimus nepolosus, using Clarias pituitary extracts and LHRHa: A thesis submitted to the graduation of Auburn University, Alabama in part fulfillment of requirements for degree of Masters of Sciences, USA.

5. Diyaware MY (2006) Studies on the effects of Carp and Clarias pituitary extracts on induced spawning of African catfish Clarias gariepinus (Burchell, 1822) in the Arid zone of Nigeria. M.Tech. Thesis submitted to the Department of Biological sciences, Federal University of Technology Yola, Adamawa State, Nigeria. 
6. De-graff A, Jonsen H (1996) Artificial reproduction and pond breeding of the African catfish Clarias gariepinus in sub-Saharan Africa. A hand book of FAO Fisheries Technical paper No 362 Rome, FAO, pp. 370.

7. Adebayo OT, Popoola OM (2008) Comparative evaluation of efficacy and cost of synthetic and non-synthetic hormones for artificial breeding of Clarias gariepinus. Journal of Fisheries and Aquatic Sciences 3 66-71.

8. Nandeesha MC, Das SK, Nathaniel DE, Varghese TR (1990) Breeding of carp with ovaprim in India. Special publication number-4, Asia Fisheries Society, India Branch, COF Mangalore, India, pp. 1-41.

9. Ndimele PE, Falayi GO (2012) Comparative reproductive and growth performance of C. gariepinus (Bruchell, 1822) and its Hybrid induced with synthetic Hormone and pituitary gland of Clarias gariepinus. Turkish Journal of Fisheries and Aquatic Sciences 12: 619-626

10. Legendre M (1986) Seasonal changes, Sexual maturity and Fecundity and Human chorionic hormone (HCG). Induced Breeding of African catfish Heterobranchus longifilis val (claridae), reared in Ebrie Lagoon (Ivory Coast). Aquaculture 55: 201-213.

11. Oyelese OA (2006) Water temperature a determinant of fertilization and hatchability rates in artificial induced breeding in Clarias gariepinus (Teleostei: clariidae ). Research Journal of Biological Sciences 1(14): 83-87.

12. Ovie SO, Ovie SI (2010) Aquaculture in Focus. Remi-Thomas Prints 119 Upper Goa-Akanbi Road, Ilorin, Kwara State, Nigeria.

13. Bagenal TB (1978) Methods of assessment of fish production in freshwater. Blackwell science publication Oxford IBP Handbook, USA, p. 35.

14. Wilson RP (1989) Amino acids and proteins in fish nutrition. In: Halver (Ed.), Academic press inc. California, USA, pp. 111-115.

15. Castell JD, Teiwa K (1980) Report of the EIFAC, IUNS and ICES working group on standardization of methodology in fish nutrition research FIPAC/736, EIFAC/FA0, p. 24.

16. Brown ME (1957) Experimental studies on growth. The Physiology of fishes. In: Brown (Ed.), New York Academy Press, Volume 1, USA p. 361-400.

17. Duncan DB (1955) Multiple ranges and multiple F-tests. Biometrics 11(1): 1-42.

18. Abdulraheem I, Otubusin SO, Agbebi OT, Olowofeso O, Adeyemi KA et al. (2012) Induced Breeding of African Catfish (Clarias gariepinus) Under Varying Brood Stock Ratios. Global Journal of Agriculture and Veterinary science 12 (8).

19. Olaniyi CO, Akinbola DO (2013) Comparative Studies on the Hatchability, Performance and Survival Rate of African Catfish (Clarias gariepinus) Larval Produced: Using Ovaprim and Catfish Pituitary Extract Hormones. Journal of Biology, Agriculture and Healthcare 3 (9).

20. Kelley CD, Lee CS (1986) Artificial propagation. In: Lee CS, et al. (Eds.), Aquaculture of milkfish (Chanos chanos). State of the Oceanic Institute, Hawaii, USA, pp. 83-116.

21. Woynarovich E, Horvath L (1980) Artificial propagation of warm water fin-fishes: A manual for extension. FAO Fish Tech Paper 201: 183.

22. Adewolu MA, Ogunsanmi AO, Yunusa A (2008) Studies on growth performance and feed utilization of two Clariid catfish and their hybrid reared under different culture systems. European Journal of Scientific Research 23(2): 252-260.

23. Ayinla OA, Kayode OJ, Idoniboye-obu OIE, Oresegun A, Adidi VE (1994) Use of Tadpole meal as substitute for fish meal in the diet of Heterobranchus bidorsalis (Geoffrey St Hillarie, 1809). Journal of Aquaculture in the Tropics 9(1): 25-33.

24. Bruton MN (1979) The breeding biology and early development of
Clarias gariepinus in Lake Sibaya, South Africa, with a review of breeding in species of the sub-genus Clarias. Transactions of the Zoological Society of London 35: 1-45.

25. Bruton MN (1979) The food and feeding behavior of Clarias gariepinus in Lake Sibaya, South Africa, with emphasis on its role as a predator of Cicchlids. Transactions of the Zoological Society of London 53: 47-114.

26. Bruton MN (1979) The Survival of habitat desiccation by air breathing clariid catfishes. Environmental Biology of Fishes 4(3): 273-280.

27. Chackroff MI (1976) Freshwater Pond culture and management VITA (Volunteers in Technical Assistance). Publication manuals 36E Peace Corps program and training. Journal manual IBUC Government printing office, Washington DC, USA.

28. Dada AA, Wonah C (2003) Production of exotic Clarias gariepinus fingerings at varying stocking densities in Outdoor concrete pond. Journal of Aquatic Sciences 18(1): 21-24.

29. Dunn JG (2000) Clarias batranchus (Linnaeus, 1758) aka walking catfish (USA) Mugier (India) kelibunga/Tong sat (melangsis) University of Texas at Aushil ichthyology 200- 334, USA, p. 6.

30. FAO (2006) Manual on catfish hatching and production. A guide to small to medium scale hatchery and fish producers in Nigeria. National Special Program for Food Security (NSFFS), pp. 3-15.

31. Hepher B (1988) Nutrition of pond fishes. Cambridge University Press, UK, p. 388.

32. Huet M (1972) Text Book of Fish Culture, Fishing News (books) ltd 23 Romont Avenue, West Byfleet survey, England Pp. 436(translated) by Henry khan from the French $4^{\text {th }}$ (edn.), of Traite de pisciculture. In: Wyngeaert B (Ed.), pp. 116-121.

33. Huisman EA, Richter CJJ (1987) Reproduction growth health control and aquatic potentials of the African catfish (Clarias gariepinus Burchell, 1822). Aquaculture 63: 1-14.

34. Idodo UG (2003) Freshwater fishes of Nigeria, taxonomy, ecological notes, diets and utilization. Idodo-Umeh Publishers, Benin, Africa, pp. 123-124.

35. Madu CT, Ita EO, Mohammed S (1999) Fish business in Africa farming and food processing January-February. p. 11-14

36. Micha JC (1973) Etude des population piscisoles de I ubangui et tentative de section et d adaptation de queiquese spaces a letang de pisci culture centre technique forester tropical, Ngemt-sur-marne pp.100.

37. Oresegun A, Oguntade OA, Ayinla OA (2007) A review of catfish culture in Nigeria. Nigerian Journal of Fisheries 4(1): 27-52.

38. Osborne TB, Wendel LB, Ferry EL (1919) A Method for expressing numerically the growth-promoting value of proteins. Journal of Biochemistry 39: 223-224.

39. Ramy M, Ashraf MA, Abd-El-Azem MA (2014) Induced spawning of African catfish, Clarias gariepinus using (gnrha) combined with dopamine antagonists. 27(1): 25-35.

40. Sileshi G, Prabha CD (2013) Evaluation of spawning induction of Africa catfish (Clarias. gariepinus) by heteroplastic hypophysation. International Journal of Fisheries and Aquaculture Studies 1(1): 22-25.

41. SPSS (2010) Software Programmed of Statistical Analysis, version 16.0 windows. SPSS Inc, Chicago, USA.

42. Van der wal BCW (1974) Observation on the breeding habit of Clarias gariepinus (BURCHELL 1822). Fish Biology 6(1): 23-27.

43. Wikipedia (2015) Location of Yola, Adamawa State- Nigeria. Retrieved.

44. World Bank (2013) Saving fish and fishers; Towards Sustainable and Equitable Governance of the Global Fisheries sector. 
(C) This work is licensed under Creative CC (1) Commons Attribution 4.0 Licens DOI: $10.19080 / J D V S .2017 .04 .555638$

\section{Your next submission with Juniper Publishers} will reach you the below assets

- Quality Editorial service

- Swift Peer Review

- Reprints availability

- E-prints Service

- Manuscript Podcast for convenient understanding

- Global attainment for your research

- Manuscript accessibility in different formats

( Pdf, E-pub, Full Text, Audio)

- Unceasing customer service

Track the below URL for one-step submission https://juniperpublishers.com/online-submission.php 